\title{
Nipah Virus: The Dreadful Outbreak in India
}

\author{
Shibani Datta*1, Nibedita Das ${ }^{2}$ and Oishi Lahiri ${ }^{3}$ \\ ${ }^{1}$ Professor, All India Institute of Hygiene \& Public Health, Kolkata, India \\ ${ }^{2}$ Microbiologist, Institute of Serology, Kolkata, India \\ ${ }^{3}$ Biomedical Engineer, Vellore Inst Of Technology, India \\ *Corresponding author: Shibani Datta, Professor, All India Institute of Hygiene \& Public Health, Kolkata, India
}

\begin{tabular}{lll}
\hline ARTICLE INFO & & ABSTRACT \\
$\begin{array}{l}\text { Received: } \\
\text { Published: February 18, } 2019\end{array}$ & & $\begin{array}{l}\text { Citation: Shibani D, Nibedita D, Oishi L. Nipah Virus: The Dreadful Outbreak in India. Bi- } \\
\text { omed J Sci \& Tech Res 15(2)-2019. BJSTR. MS.ID.002675. }\end{array}$ \\
\hline
\end{tabular}

\section{Short Communication}

The Nipah virus outbreak in Kerala state has jolted the health system of the state recently. On 19 May 2018, three deaths due to Nipah virus (NiV) infection were reported in Kozhikode District, Kerala State, India. The three deaths occurred in a family cluster and a fourth death was subsequently reported in a health care worker who was involved in treatment of the family in the local hospital [1].

Since the beginning of the outbreak, as a result of further investigations and contact tracing, 15 people had been tested positive for NiV in Kozhikode and Malappuram districts, Kerala State. Of the 15 laboratory-confirmed cases, two were hospitalized and thirteen had died, including the health care worker who was involved in treatment of the deceased [2]. This indicates the high case fatality rate of the virus. India faced the first outbreak in 2001 in Siliguri of West Bengal and the second outbreak in 2007 in the Nadia Districts. Total 71 cases were affected in the two outbreaks with a death of 50 affected persons [3].

Nipah virus, a paramyxo virus related to Hendra virus, first emerged in Malaysia in the year 1998 in a village known as Kampung Sungai Nipah [4]. The virus's natural hosts are considered to be fruit bats of the Pteropodidae Family, Pteropus genus. The virus can be transmitted to human being from sick pig or from the secretions of fruit bats. This zoonotic disease also has human to human transmission which occurs by close contact. Consumption of fruits partially eaten by bats and date palm sap contaminated by the infected fruit bats can cause the disease.

The incubation period of the disease is 4 to 14 days which can extend for 60 days. The symptoms are fever, headache, sore throat, vomiting, dizziness etc. Encephalitic symptoms are also common [5]. Since no cure or vaccine is available till date to combat the disease, intensive supportive treatment is the only choice for treating severe respiratory or neurological complications. Laboratory testing of throat swabs, urine and blood samples collected from the suspected cases had been conducted in Institute of Viral Research, Manipal and reconfirmed by National Institute of Virology, Pune. The cases were confirmed positive for Nipah virus by real-time polymerase chain reaction (RT-PCR) and IgM ELISA for NiV.

All the cases were admitted to the Kozhikode District Hospital where Government undertook containment measures. As the Nipah virus outbreak was declared in the State of Kerala, the Health Department proceeded to upgrade the safety protocol at the Kozhikode Medical College where all the cases would be brought. All the doctors and health staffs were instructed to use universal protective equipment's to combat the viral transmissions from the patients. The Kozhikode panchayat, the epicentre of the disease was directed to spread the awareness campaign by the ASHA and AWW among the community regarding the modes of viral transmission. A team was sent from NCDC (National Centre for Disease Control) and AIIMS, New Delhi to the affected area. Meanwhile those who reported with fever were admitted and isolated in the Hospital. The Kerala Government started supplying Ribavirin for its antiviral activity.

At present there is no specific treatment available for the infection except giving intensive supportive therapy. As treatment options are limited, focus on $\mathrm{NiV}$ management should be on 
prevention. People should be made aware to prevent direct contact with sick pig and bats. Consumption of fruits partially eaten by bats as well as raw date palm sap/toddy/juice in the endemic area should be prohibited. The health personnel should implement standard infection prevention and control measures while taking care of NiV infected patients to combat the spread of nosocomial infection.

A number of vaccine candidates have been found to be capable of complete protection against $\mathrm{NiV}$ disease in preclinical studies of small animals and non-human primate models [6]. While WHO has declared $\mathrm{NiV}$ to be a priority pathogen, research is going on to develop safe, effective and affordable vaccines for such diseases with pandemic potential. More advanced research is necessary regarding the ecology of the bats and virus to prevent such dreadful infection in future.

\section{ISSN: 2574-1241}

DOI: 10.26717/BJSTR.2019.15.002675

Shibani Datta. Biomed J Sci \& Tech Res

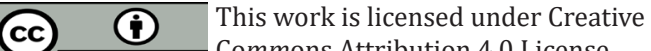

Submission Link: https://biomedres.us/submit-manuscript.php

\section{References}

1. http://www.who.int/csr/don/31-may-2018-nipah-virus-india/en/

2. (2018) Antibody to Fight Nipah Reaches Kozhikode. The Hindu.

3. Chadha MS, Comer JA, Lowe L, Rota PA, Rollin PE, et al. (2006) Nipah virus associated encephalitis outbreal, Siliguri, India. Emerging Infect Dis 12(2): 235-240.

4. Chua KB, Bellini WJ, Rota PA, Harcourt BH, Tamin A, et al. (2000) Nipah virus: A recent emergent deadly paramyxovirus. Science 288(5470): 1432-1435.

5. Goh KJ, Tan CT, Chew NK, Tan PS, Kamarulzaman A, et al. (2000) Clinical features of Nipah virus encephalitis among pig farmers in Malaysia. N Engl J Med 342(17): 1229-1235.

6. Satterfield BA, Dawes BE, Milligan GN (2016) Status of vaccine research and development of vaccines for Nipah virus. Vaccines 34(26): 29712975.

$\begin{array}{ll}\text { BIOMEDICAL } & \text { Assets of Publishing with us } \\ \text { RESEARCHES } & \text { - Global archiving of articles } \\ & \text { - Immediate, unrestricted online access } \\ & \text { - Rigorous Peer Review Process } \\ \end{array}$

